Ludwik Wicki ${ }^{1}$

Szkoła Glówna Gospodarstwa Wiejskiego w Warszawie

\title{
Poziom i zakres wsparcia upowszechniania postępu biologicznego w produkcji roślinnej w ramach działań Agencji Rynku Rolnego
}

\section{THE LEVEL AND SCOPE OF SUPPORT OF BIOLOGICAL PROGRESS DISSEMINATION IN CROP PRODUCTION IN POLAND WITHIN THE MEASURES OF AGRICULTURAL MARKET AGENCY}

Wzrost produktywności roślin jest uzyskiwany głównie poprzez postęp w hodowli odmian. Z tego powodu wykorzystanie nasion kwalifikowanych $w$ produkcji jest bardzo ważne, a realizowany program ma doprowadzić wyższego poziomu zużycia nasion kwalifikowanych. Celem opracowania jest ocena poziomu i zakresu wsparcia upowszechniania kwalifikowanego materiatu siewnego $w$ Polsce w ramach działania Agencji Rynku Rolnego oraz określenie przestrzennego jego zróżnicowania. Analizq objęto caly okres realizacji działania, czyli lata 2007-2016.

Stwierdzono, że wsparcie do obejmowało prawie cała podaż kwalifikowanego ziarna zbóż oraz sadzeniaków ziemniaka $w$ Polsce $i$ dotyczyto około ponad $1 \mathrm{mln}$ ha rocznie, $w$ tym średnio $14 \%$ powierzchni zasiewów zbóż i 10\% powierzchni produkcji ziemniaków. Korzystanie z programu byto silnie zróżnicowane regionalnie. W regionach o wyższym poziomie rozwoju rolnictwa objęto nim ponad $10 \%$ gospodarstw i $20 \%$ powierzchni zasiewów. W regionach ze stabym i rozdrobnionym rolnictwem byto to tylko $1 \%$ gospodarstw i około 4\% powierzchni zasiewów. Zainteresowanie wdrażaniem postępu biologicznego $w$ warunkach rozdrobnionego rolnictwa utrzymuje się na niskim poziomie, a oferowane wsparcie nie byto skuteczne.

Slowa klucze: nasiona kwalifikowane, postęp biologiczny, pomoc de minimis, upowszechnianie postępu, wsparcie rolnictwa

\section{Wstęp}

Wprowadzanie postępu technicznego w rolnictwie jest jednym z ważniejszych czynników wpływających na wzrost produktywności użytkowanych zasobów. Dla całego świata udział postępu technicznego w ogólnym wzroście produktywności w rolnictwie został oszacowany dla lat 2001-2014 na około 67,3\%, przy czym w krajach rozwiniętych następował wzrost produkcji mimo spadku nakładów. Średni roczny wzrost produkcji wynosił 2,54\%, w tym wzrost wynikający $\mathrm{z}$ wprowadzania postępu oszacowano na $1,71 \%$ rocznie $^{2}$. Dla Polski zmianę produkcji rolniczej wynikającą z postępu technicz-

\footnotetext{
${ }^{1}$ dr hab. inż., prof. nadzw. Katedra Ekonomiki i Organizacji Przedsiębiorstw, Wydział Nauk Ekonomicznych, ${ }^{2}$ Fuglie, K., Rada, N. 2017. International Agricultural Productivity, USDA, Economic Research Service. dostepne na: https://www.ers.usda.gov/data-products/international-agricultural-productivity/ (dostęp: 21.10.2017).
} 
nego określono dla tego okresu na 1,5\% średniorocznie. Postęp biologiczny jest jednym $\mathrm{z}$ ważniejszych składowych postępu w rolnictwie i wynika z wprowadzania do produkcji nowych, lepszych odmian roślin i udoskonalonych ras zwierząt. Udział postępu biologicznego w kreowaniu wzrostu produktywności w produkcji roślinnej szacuje się dla krajów rozwiniętych na $30-50 \% \mathrm{w}$ zależności od gatunku ${ }^{3,4,5,6}$. Dla warunków polskich wielkość tę oszacowano dla okresu 1985-2004 na poziomie około 7-10\% w warunkach polowych $^{7,8}$, a dla warunków doświadczeń poletkowych było 30-60\% w zależności od gatunku i poziomu intensywności uprawy?.

Upowszechnianie postępu biologicznego w produkcji roślinnej następuje przez stosowanie nowych odmian i kwalifikowanego materiału siewnego. Im mniejsze jest zużycie nasion kwalifikowanych, tym powolniejszy jest proces upowszechniania. Biorąc pod uwagę to, że postęp biologiczny ma zwykle charakter egzogeniczny względem gospodarstw rolniczych, a jedną $\mathrm{z}$ barier jego wprowadzania jest wysoki koszt dla rolników, w Polsce przez wiele lat stosowano dopłaty do zakupu kwalifikowanego materiału siewnego. Do 2003 roku dotacje do upowszechniania nasion kwalifikowanych stanowiły nawet ponad $40 \%$ dotacji przeznaczanych na wspieranie postępu biologicznego ${ }^{10}$, a kwoty dotacji w niektórych latach wynosiły nawet $95 \mathrm{mln}$ złotych rocznie. Dotacją do obniżenia cen objęte było prawie $100 \%$ sprzedaży kwalifikowanych nasion zbóż i sadzeniaków ziemniaka. Dotacje wypłacano rocznie do 150-200 tys. ton ziarna zbóż i do około 70 tys. ton sadzeniaków. W 2004 roku zaprzestano tej formy wsparcia, gdyż była ona niezgodna z zasadami wspierania rolnictwa w Unii Europejskiej.

Pomoc dla rolników mająca na celu zwiększenie zakresu wykorzystania nasion i sadzeniaków kwalifikowanych w produkcji roślinnej została ponownie wprowadzona w 2007 roku jako pomoc de minimis. Impulsem podjęcia działania była, oprócz zamiaru wsparcia korzystania z nasion kwalifikowanych, susza, która doprowadziła do niedoboru nasion o jakości odpowiedniej do siewu. Od 2007 roku Agencja Rynku Rolnego (ARR) udziela rolnikom wsparcia finansowego $\mathrm{z}$ budżetu krajowego z tytułu zużytego do siewu lub sadzenia kwalifikowanego materiału siewnego. Wsparcie było udzielane na podstawie ustawy z dnia 11 marca 2004 roku o Agencji Rynku Rolnego i organizacji niektórych rynków rolnych oraz rozporządzenia Komisji (UE) nr 1408/2013. Dopłaty były naliczane do powierzchni gruntów „ornych obsianych lub obsadzonych kwalifikowanym

\footnotetext{
${ }^{3}$ P. Gepts, „Genetic Diversity, Plant Breeding, and Sustainability”, University of California, Davis, 2003.

${ }^{4}$ D. Duvick, „The Contribution of Breeding to Yield Advances in Maize (Zea mays L.)”, Advances in Agronomy, 2005, vol. 86, 83-145.

${ }^{5}$ H. Witzke, K. Jechlitschka, D. Kirschke, H. Campen, S. Noleppa, „Social rate of return to plant breeding research in Germany, „Agrarwirtschaft”, 2004, t. 53, z. 5, 206-210.

${ }^{6}$ C. Thirtle Technological Change and the Productivity Slowdown in Field Crops: United States, 1939-78. „Southern Journal of Agricultural Economics”, 1995, 17 (Dec.), 33-42.

${ }_{7}$ L. Wicki, Poziom i efekty stosowania materiału kwalifikowanego w gospodarstwach rolniczych, „Roczniki Naukowe SERiA", 2006, t. VIII, z. 1, 222-226.

${ }^{8}$ L. Wicki, „Efekty upowszechniania postępu biologicznego w produkcji roślinnej”, Wydawnictwo SGGW, Warszawa, 2010.

${ }^{9}$ L. Wicki, Postęp w plonowaniu odmian pszenicy ozimej i żyta w doświadczeniach odmianowych w Polsce, „Roczniki Naukowe SERiA”, 2017, t. XIX, z. 4, 2017, 224-230.

${ }^{10} \mathrm{~L}$. Wicki, Zróżnicowanie przestrzenne wykorzystania postępu biologicznego w produkcji roślinnej w Polsce, „Roczniki Nauk Rolniczych, Seria G”, 2010, t. 97, z 4, 221-229.
} 
materiałem siewnym zbóż, strączkowych i ziemniaka ${ }^{11}$. Wsparcie to jest realizowane corocznie do chwili obecnej. Uruchomienie działania było wskazywane także jako czynnik prowadzący do utrzymania polskiej hodowli roślin, gdyż kreowało popyt na nasiona $^{12}$. Mimo to, sytuacja polskich hodowców pogarszała się ze względu na rosnącą konkurencję hodowli zagranicznych ${ }^{13}$. W innych badaniach wskazywano na pozytywny wpływ dedykowanego wsparcia na zakupy środków do produkcji w gospodarstwach ${ }^{14}$.

Mając na uwadze duże znaczenie postępu biologicznego w kreowaniu wzrostu produkcyjności w rolnictwie, a także potrzebę oceny korzystania przez rolników z dedykowanego temu mechanizmu wsparcia, podjęto tematykę dotyczącą roli działania realizowanego ze środków krajowych przez Agencję Rynku Rolnego zakresie w upowszechniania postępu biologicznego. Większość działań dotyczących modernizacji polskiego rolnictwa była realizowana $w$ ramach programów wspólnej polityki rolnej UE, przede wszystkim PROW ${ }^{15}$. Działania takie, mimo że ukierunkowane także na wprowadzanie zmian mających na celu ograniczanie zużycia środków produkcji i zmniejszenie wpływu rolnictwa na środowisko, nie obejmują finansowania postępu biologicznego ${ }^{16}$.

\section{Cel i metodyka badań}

Celem opracowania jest ocena poziomu i zakresu wsparcia upowszechniania kwalifikowanego materiału siewnego w Polsce w ramach działania Agencji Rynku Rolnego oraz określenie przestrzennego jego zróżnicowania.

Dla osiagnięcia celu zrealizowano następujące zadania badawcze: (1) określono wartość wsparcia, liczbę beneficjentów oraz powierzchnię, do której udzielono wsparcia, (2) ustalono intensywność wsparcia w odniesieniu do liczby gospodarstw i powierzchni upraw w Polsce, (3) ustalono, jakie było zróżnicowanie przestrzenne wykorzystania udzielanej pomocy.

Dane do analizy pochodziły z raportów Agencji Rynku Rolnego dotyczących realizacji omawianego działania, a więc liczby wniosków, kwoty środków wydatkowanych i powierzchni objętej wsparciem, $\mathrm{z}$ uwzględnieniem realizacji działania w poszczególnych województwach. Pod uwagę wzięto wszystkie dotychczasowe edycje działania, czyli okres 2007-2016. Dane dotyczące powierzchni upraw w Polsce i w konkretnych województwach pochodzą z publikacji statystycznych GUS, a liczbę aktywnych gospodarstw rolnych przyjęto na podstawie liczby wniosków o płatności bezpośrednie składanych do Agencji Restrukturyzacji i Modernizacji Rolnictwa. W analizie posłużono się głównie wskaźnikami dynamiki, struktury i intensywności.

\footnotetext{
${ }^{11}$ Szczegółowy wykaz gatunków objętych wsparciem ogłaszany był w rozporządzeniach Ministra Rolnictwa i Rozwoju Wsi.

${ }^{12}$ K. Marciniak, Stan polskiej hodowli roślin w roku 2008, „Roczniki Nauk Rolniczych, Seria G” 2008, t. 95 , z. $1,166-173$.

${ }_{13}$ D. Majchrzycki, Rynek kwalifikowanego materiału siewnego pszenicy ozimej w Polsce. „Roczniki Naukowe SERiA", 2015, t. XVII, z. 3, 254-259.

${ }^{14}$ D. Kusz, S. Gędek, Egzogeniczne i endogeniczne uwarunkowania inwestycji w rolnictwie w Polsce. „Roczniki Naukowe SERiA”, 2015, t. XVII, z. 3, 237-242.

${ }_{15}$ B. Gołębiewska, Inwestycje i źródła ich finansowania w gospodarstwach o zróżnicowanych powiązaniach z otoczeniem. „Roczniki Naukowe SERiA”, 2010, t. XII, z. 3, 88-92.

${ }^{16}$ A. Mickiewicz, B. Mickiewicz, Charakterystyczne cechy nowego Programu Rozwoju Obszarów Wiejskich na lata 2014-2020. „Roczniki Naukowe SERiA”, 2015, t. XVII, z 1, 153-158.
} 
Założono, że wyższe wykorzystanie dotacji do stosowania kwalifikowanego materiału siewnego wskazuje na wyższy poziom rozwoju rolnictwa w zakresie produkcji roślinnej, a jednocześnie oznacza lepsze wykorzystanie pozostałych czynników produkcji. Tak więc oznacza to zarówno, że rolnictwo jest na wyższym poziomie rozwoju, jak też charakteryzuje się bardziej zrównoważonym wykorzystaniem nakładów produkcyjnych.

\section{Poziom udzielanego wsparcia do stosowania materiału siewnego}

Agencja Rynku Rolnego rozpoczęła udzielanie wsparcia do wykorzystania materiału kwalifikowanego w 2007 roku. Realizowano je zgodnie z regulacjami krajowymi i rozporządzeniem Komisji (WE) nr 1860/2004 w sprawie stosowania art. 87 i 88 Traktatu WE $\mathrm{w}$ odniesieniu do pomocy $\mathrm{w}$ ramach zasady de minimis dla sektora rolnego i sektora rybołówstwa. Zasady wsparcia uregulowano w rozporządzeniu Rady Ministrów ${ }^{17}$. Było to działanie podjęte $\mathrm{w}$ odpowiedzi na zgłaszane postulaty rolników i hodowców, aby wspierać upowszechnianie korzystania z kwalifikowanego materiału siewnego jako elementu wprowadzania postępu w rolnictwie, oraz w związku z suszą i niską jakością własnego materiału siewnego.

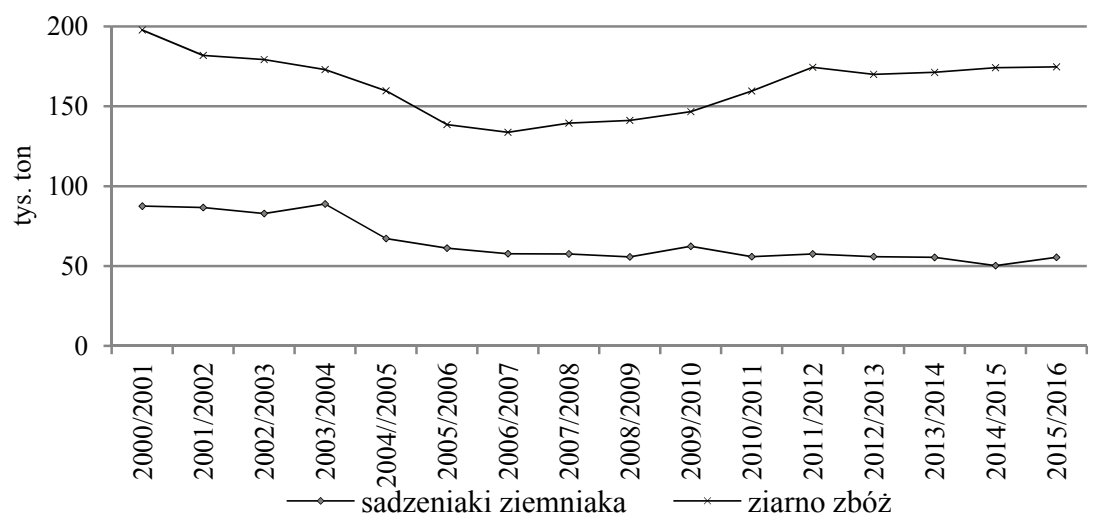

Rysunek 1. Zużycie kwalifikowanego materiału siewnego zbóż i kwalifikowanych sadzeniaków ziemniaka w Polsce w latach 2000-2016

Źródło: opracowanie własne na podstawie danych GUS.

Po zaprzestaniu wypłacania bonifikat do kwalifikowanego materiału siewnego na rynku kwalifikowanych nasion zbóż i sadzeniaków ziemniaka obserwowano stagnację. W 2006 roku w Polsce sprzedano 134 tys. ton kwalifikowanego ziarna zbóż, o 25\% mniej niż w 2002 roku i aż o 36\% mniej niż w 2000 roku. Podobnie, sprzedaż kwalifikowanych sadzeniaków ziemniaka zmniejszyła się o 34\% w latach 2000-2006 (rys. 1). Udział nasion kwalifikowanych $\mathrm{w}$ materiale siewnym obniżył się do około $10 \%$, a w krajach tzw. UE-15 było to około $50 \%{ }^{18}$. Stało się to impulsem do wprowadzenia

\footnotetext{
${ }^{17}$ Rozporządzenie Rady Ministrów z dnia 13 marca 2007 roku w sprawie wykazu gatunków roślin uprawnych, do których materiału siewnego kategorii elitarny lub kwalifikowany przysługuje dopłata z tytułu zużytego do siewu lub sadzenia materiału siewnego kategorii elitarny lub kwalifikowany (Dz. U. Nr 46, poz. 300).

${ }^{18}$ L. Wicki, Zmiany w zużyciu nasion kwalifikowanych w Polsce, „Roczniki Nauk Rolniczych, seria G”, 2009 , t. 96, z. $4,226-237$.
} 
mechanizmu, który zapewniałby większą skalę dopływu nasion kwalifikowanych do rolnictwa. Podjęte przez ARR działanie było podobne do wsparcia realizowanego przed integracją z UE, lecz nie było teraz udzielane do sprzedaży nasion, ale do powierzchni, na której zastosowano nasiona kwalifikowane. Dotacja trafiała więc do rolników, a następnie, poprzez zakup nasion, do firm nasiennych i hodowlanych. Przed 2004 roku dotację rozliczały podmioty zajmujące się obrotem nasionami kwalifikowanymi.

W 2007 roku ARR wypłaciła 19,4 mln złotych dotacji udzielając wsparcia do około 300 tys. hektarów. W 2008 roku kwota dotacji wzrosła już do 67 mln złotych i w kolejnych latach zwiększała się. Dopiero w 2016 roku, w związku z obniżeniem stawek, wypłacona dotacja uległa zmniejszeniu w stosunku do 2015 roku i była na poziomie kwot wypłacanych w latach 2011-2013. Zmiany te przedstawiono na rysunku 2.

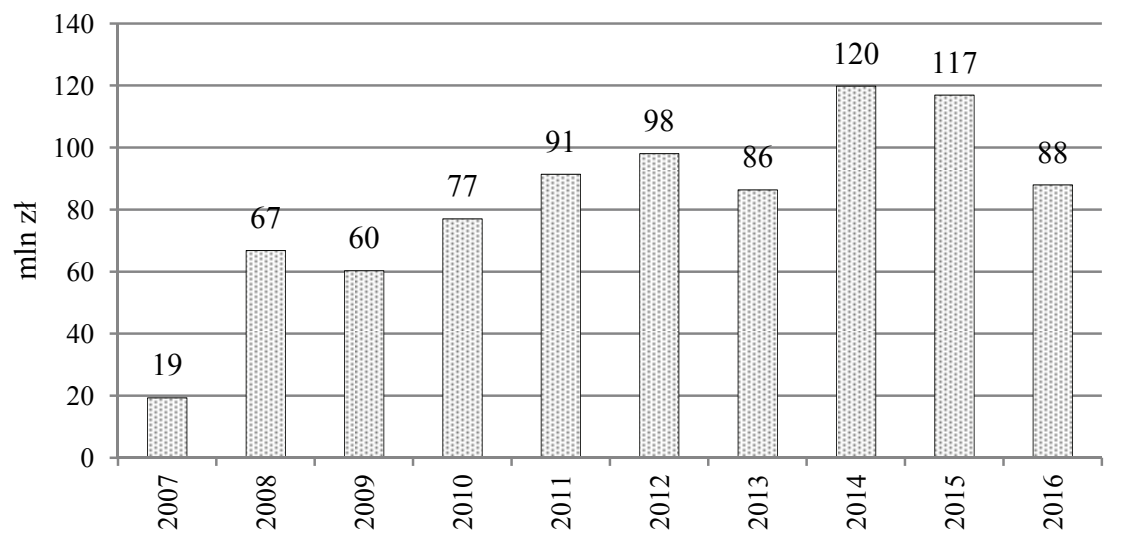

Rysunek 2. Kwoty dopłat do powierzchni obsianej lub obsadzonej kwalifikowanym materiałem siewnym wypłacone przez Agencję Rynku Rolnego w latach 2007-2016

Źródło: opracowanie własne na podstawie sprawozdań ARR.

W kolejnych latach stawki dotacji ulegały zmianom. Początkowo wypłacano $50 \mathrm{zł} / \mathrm{ha}$ do powierzchni zbóż obsianej materiałem kwalifikowanym oraz $300 \mathrm{z} /$ ha do powierzchni ziemniaków obsadzonej sadzeniakami kwalifikowanymi. Na 2008 rok stawki te podniesiono do $100 \mathrm{zz} / \mathrm{ha} \mathrm{i} 500 \mathrm{zł} / \mathrm{ha}$. Dotacja do roślin strączkowych wynosiła $160 \mathrm{z}$ /ha. Stawki te nie ulegały zmianom do 2015 roku. Od 15 kwietnia 2015 roku zostały obniżone do poziomu $80 \mathrm{zł} / \mathrm{ha}$ dla zbóż, $130 \mathrm{zt} / \mathrm{ha}$ dla strączkowych i $400 \mathrm{zt} / \mathrm{ha}$ dla ziemniaków. W 2016 roku było to jeszcze mniej: $69,40 \mathrm{zł} / \mathrm{ha}$ dla zbóż, $111 \mathrm{zł} / \mathrm{ha}$ dla strączkowych i $347 \mathrm{zł} /$ ha dla ziemniaków Obniżenie dotacji jednostkowej prowadziło do wypłaty mniejszej kwoty dotacji przy podobnej powierzchni, do której udzielono wsparcia.

Poziom dotacji jednostkowej nie pokrywał kosztu zakupu materiału kwalifikowanego używanego do siewu lub sadzenia. W zależności od zastosowanej normy wysiewu, kwota dotacji wystarczała na pokrycie od 30 do $35 \%$ kosztu zakupu ziarna kwalifikowanego lub sadzeniaków kwalifikowanych. Istotą wsparcia nie było więc sfinansowanie zakupu nasion kwalifikowanych lecz zachęcenie rolników do ich wykorzystania poprzez dofinansowanie ich zakupu i w ten sposób uzyskanie upowszechnienia postępu biologicznego w postaci nowych odmian i nasion kwalifikowanych. 
Podjęte działania przyniosły zamierzony skutek. Zahamowany został spadek poziomu zużycia nasion kwalifikowanych, a jednocześnie wsparciem objęto znaczny areał produkcji, głównie zbóż i ziemniaków, ale też roślin strączkowych. Powierzchnia objęta wsparciem w 2008 roku wynosiła już prawie 600 tys. ha, a w kolejnych latach dalej wzrastała, do około 1,2 mln ha w 2015 roku (rys. 3). W całym okresie największy udział miały zboża, od 93 do $96 \%$ powierzchni objętej wsparciem. Około 3\% powierzchni objętej dotacjami uprawy stanowiły ziemniaki, a resztę rośliny strączkowe.

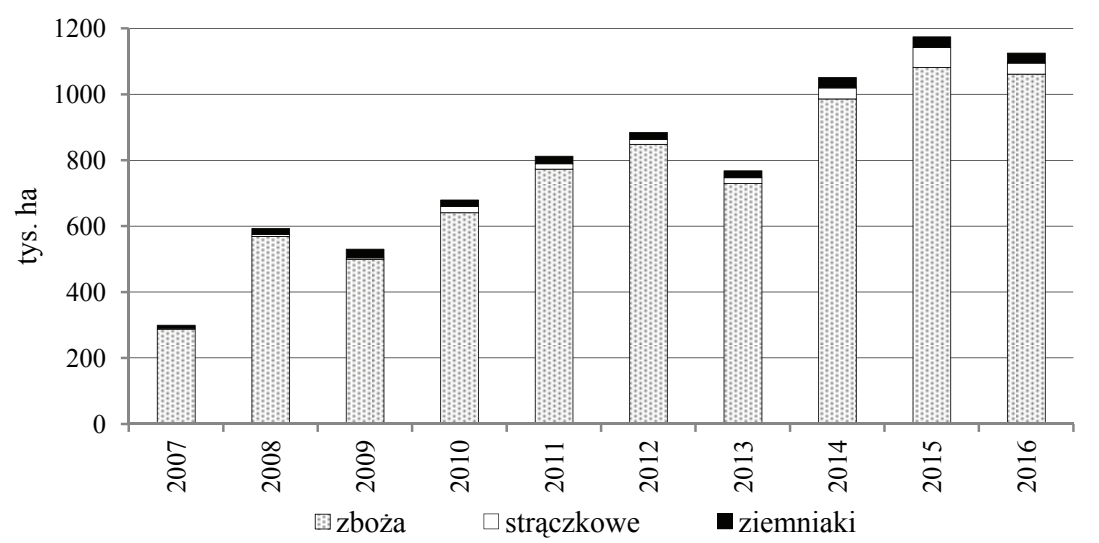

Rysunek 3. Powierzchnia produkcji objęta wsparciem do powierzchni obsianej lub obsadzonej kwalifikowanym materiałem siewnym w latach 2007-2016

Źródło: opracowanie własne na podstawie sprawozdań ARR.

Wielkość i struktura powierzchni objętej wsparciem nie daje podstawy do oceny poziomu realizowanej pomocy. Produkcja zbóż podstawowych i ich mieszanek była prowadzona na powierzchni prawie $7 \mathrm{mln}$ ha, a produkcja ziemniaków zajmowała około 300-400 tys. ha. W efekcie, udział powierzchni produkcji roślin, do których udzielano wsparcia był mniej zróżnicowany gatunkami niż wynika z rysunku 3. Oszacowany udział został przedstawiony w tabeli 1 . Dla zbóż było to od 6 do $14 \%$, a dla ziemniaków od 3 do prawie $12 \%$. W tabeli 1 przedstawiono także oszacowaną ilość kwalifikowanego ziarna zbóż i kwalifikowanych sadzeniaków ziemniaka zużytych do siewu lub sadzenia na powierzchni objętej wsparciem.

Wraz ze wzrostem wypłacanych kwot dotacji oszacowana ilość materiału siewnego pośrednio objęta wsparciem zwiększała się. Po 2010 roku dla zbóż było to od 116 do 173 tys. ton, a dla ziemniaków od 33 do 50 tys. ton. Porównując te wielkości z danymi o sprzedaży kwalifikowanego materiału siewnego według GUS można stwierdzić, że w latach, dla których określono najwyższą ilość materiału objętego wsparciem, prawie $100 \%$ sprzedaży materiału kwalifikowanego zużyto na powierzchni objętej programem wsparcia realizowanym przez ARR. Dla zbóż udział ten wahał się od 55\% w 2009 roku do nawet 99\% w 2015 roku. Podobnie dla ziemniaków było to od 50\% w latach 2008 i 2010 do prawie 100\% w 2015 roku. Oznacza to, że dotacje do nasion kwalifikowanych obejmują większość, a w niektórych latach nawet prawie cały rynek nasion gatunków objętych tym działaniem. Biorąc pod uwagę oszacowany na około 33\% poziom pokrycia ceny zakupu nasion dotacją, oznacza to jednocześnie, że w latach 2010-2016 aż 33\% rynku nasion finansowane było pośrednio $z$ dotacji wypłacanych przez ARR. 
Tabela 1. Udział powierzchni zbóż i ziemniaków objętych wsparciem do stosowania kwalifikowanego materiału siewnego i szacunkowa ilość materiału siennego zużytego na powierzchni objętej wsparciem w latach 2007-2016

\begin{tabular}{|l|c|c|c|c|}
\hline \multirow{2}{*}{ Rok } & \multicolumn{2}{|}{$\begin{array}{c}\text { Udział powierzchni zasiewów* } \\
\text { objętej wsparciem, w \% }\end{array}$} & $\begin{array}{c}\text { Szacunkowa ilość kwalifikowanego materiału siewnego } \\
\text { zużyta na powierzchni objętej wsparciem, w tys. ton** }\end{array}$ \\
\cline { 2 - 5 } & zboża & ziemniaki & zboża & ziemniaki \\
\hline 2007 & 3,6 & 1,6 & 46,1 & 14,4 \\
\hline 2008 & 6,9 & 3,4 & 91,1 & 28,5 \\
\hline 2009 & 6,1 & 5,4 & 79,8 & 42,5 \\
\hline 2010 & 8,9 & 5,1 & 102,6 & 31,6 \\
\hline 2011 & 10,5 & 5,8 & 123,7 & 36,4 \\
\hline 2012 & 12,0 & 5,9 & 135,8 & 34,0 \\
\hline 2013 & 10,8 & 6,2 & 116,8 & 33,2 \\
\hline 2014 & 14,7 & 11,8 & 157,8 & 50,5 \\
\hline 2015 & 14,4 & 10,8 & 173,1 & 50,7 \\
\hline 2016 & 14,2 & 10,0 & 169,9 & 48,6 \\
\hline
\end{tabular}

* - powierzchnia zasiewów zbóż podstawowych z mieszankami w analizowanym okresie wynosiła 6,7-8 mln ha, a powierzchnia produkcji ziemniaków zmniejszała się z około 0,5 do $0,3 \mathrm{mln}$ ha; ** _ założono średnie zużycie kwalifikowanego ziarna zbóż na 1 ha w ilości 170 kg oraz zużycie kwalifikowanych sadzeniaków ziemniaka na 1 ha w ilości $1700 \mathrm{~kg}$.

Źródło: opracowanie własne.

Agencja Rynku Rolnego wypłacała dotacje dla 55-75 tysięcy beneficjentów w zależności od roku realizacji działania. Wskazana liczba gospodarstw rolnych jest relatywnie nieduża w stosunku do ogólnej liczby około 1,35 mln aktywnych gospodarstw rolnych w Polsce. W zależności od roku, o wsparcie do powierzchni, na której stosowano kwalifikowany materiał siewny ubiegało się od 3,3 do 5,6\% ogólnej liczby gospodarstw (rys. 4). Odsetek powierzchni wspieranej był znacznie wyższy niż odsetek gospodarstw. Jest to $1,8-2,5$ razy więcej (tab. 1 i rys. 4). Przeciętna powierzchnia wspierana przypadająca na jednego beneficjenta wynosiła od 11 do 15 ha zależnie od roku. Oznacza to, że o wsparcie ubiegały się gospodarstwa o większej niż średnio powierzchni. Można oszacować, że były to gospodarstwa o średniej powierzchni około 20-25 hektarów. Wynika z tego, że postęp biologiczny w produkcji roślinnej jest wprowadzany do produkcji przede wszystkim w gospodarstwach większych obszarowo i to właśnie takie gospodarstwa mają szanse rozwoju, o ile wprowadzanie postępu ma miejsce także w innych sferach. W gospodarstwach małych istnieją istotne bariery dla wprowadzania postępu, w tym postępu biologicznego, trudne do przełamania nawet przy stosowaniu bodźców w formie dotacji.

\section{Regionalne zróżnicowanie wykorzystania wsparcia do stosowania kwalifikowanego materiału siewnego}

W realizacji wsparcia do powierzchni, na której zastosowano kwalifikowany materiał siewny obserwowane były znaczne różnice między poszczególnymi województwami. Dla uzyskania porównywalności danych dokonano oceny, jaki procent powierzchni zasiewów zbóż i ziemniaków był objęty wsparciem, a także określono, jaka była intensywność aplikowania o wsparcie wśród gospodarstw. Ze względu na to, że działanie zostało uruchomione w 2007 roku i w pierwszym roku funkcjonowania nie było powszechnie znane, oceniono wyniki za lata 2008-2016. 
Ogółem w okresie 2008-2016 corocznie wnioski o wsparcie do wykorzystania kwalifikowanego materiału siewnego składało około 4,5\% gospodarstw. Najwięcej wniosków składano w województwach: kujawsko-pomorskim, wielkopolskim, opolskim i dolnośląskim, a najmniej w województwach małopolskim, świętokrzyskim i podkarpackim (rys. 5). Uzyskana zależność potwierdza wcześniej podane ustalenie, że zainteresowanie

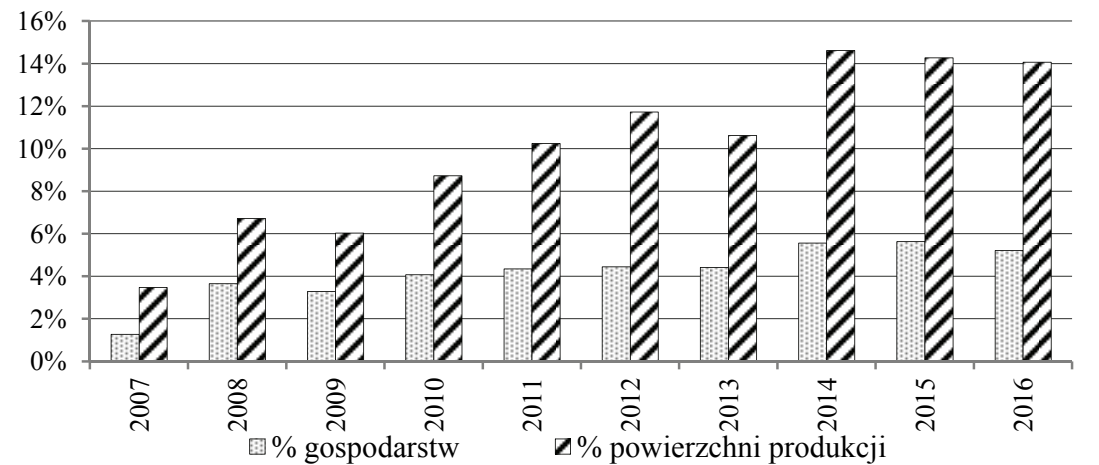

Rysunek 4. Udział gospodarstw rolnych otrzymujących wsparcie i udział powierzchni zasiewów objętej wsparciem do powierzchni obsianej lub obsadzonej kwalifikowanym materiałem siewnym w latach 2007-2016 Źródło: opracowanie własne na podstawie sprawozdań ARR.

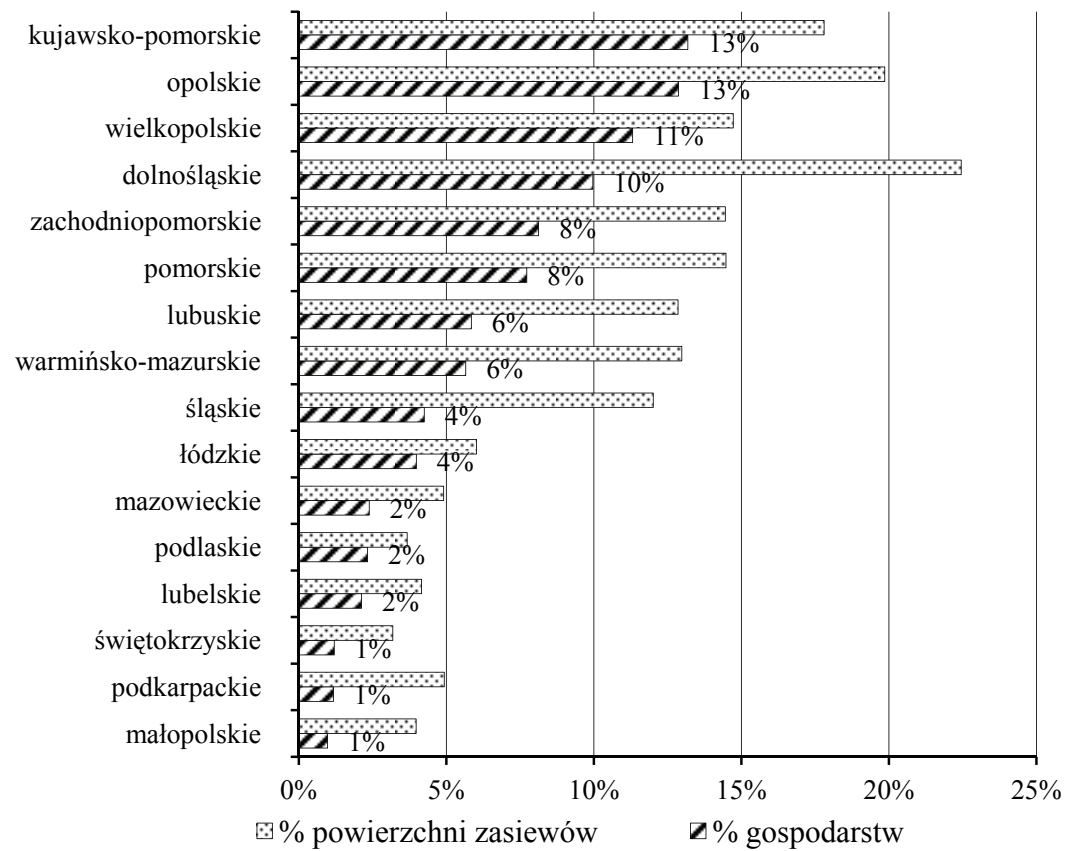

Rysunek 5. Udział gospodarstw rolnych otrzymujących wsparcie do powierzchni obsianej lub obsadzonej kwalifikowanym materiałem siewnym oraz udział powierzchni zasiewów objętej wsparciem według województw (średnio w latach 2008-2016)

Źródło: opracowanie własne na podstawie sprawozdań ARR i danych ARiMR. 
stosowaniem kwalifikowanego materiału siewnego wyrażali przede wszystkim rolnicy posiadający większe niż przeciętnie gospodarstwa rolne. Nie jest to zależność czysto liniowa, gdyż w czterech województwach o największej średniej powierzchni gospodarstw (zachodniopomorskie, warmińsko-mazurskie, lubuskie i pomorskie) około 5,6\% rolników wnioskowało o wsparcie, a w czterech wymienionych wyżej województwach z najwyższym zainteresowaniem korzystaniem z działania udział ten wynosił $12 \%$.

Zróżnicowany według województw był także udział powierzchni zasiewów objętych działaniem. Uzyskane wyniki były silnie skorelowane z przedstawionymi dla udziału gospodarstw. W trzech województwach o najintensywniejszym korzystaniu z programu udział powierzchni wspieranej $\mathrm{w}$ powierzchni zasiewów przekraczał 15\%, a w sześciu o najniższym zainteresowaniu programem był mniejszy niż 5\% (rys. 5).

Przedstawione zróżnicowanie regionalne poziomu zainteresowania programem wsparcia do stosowania kwalifikowanego materiału siewnego było trwałe. Mimo pewnych wahań w kolejnych latach, wyraźne jest ukształtowanie się dwóch głównych grup województw (rys. 6). Z Z jednej strony jest grupa siedmiu województw z udziałem powierzchni zasiewów objętej wsparciem poniżej $7 \%$. Z tej grupy na plus odchylają się tylko wyniki uzyskane dla województwa łódzkiego. Z drugiej strony obserwuje się dość niejednorodną grupę dziewięciu województw, w których udział powierzchni zasiewów objętej wsparciem był wysoki i wynosił w 2016 roku od 15 do $25 \%$. Uzyskane wyniki dają podstawę do stwierdzenia, że postawy rolników w zakresie korzystania z kwalifikowanego materiału siewnego są relatywnie stałe także w ujęciu regionalnym. Nie obserwowano bowiem znaczących zmian $\mathrm{w}$ rankingu województw $\mathrm{w}$ badanym okresie, a w innych badaniach także uzyskano podobny rozkład województw ${ }^{19}$.

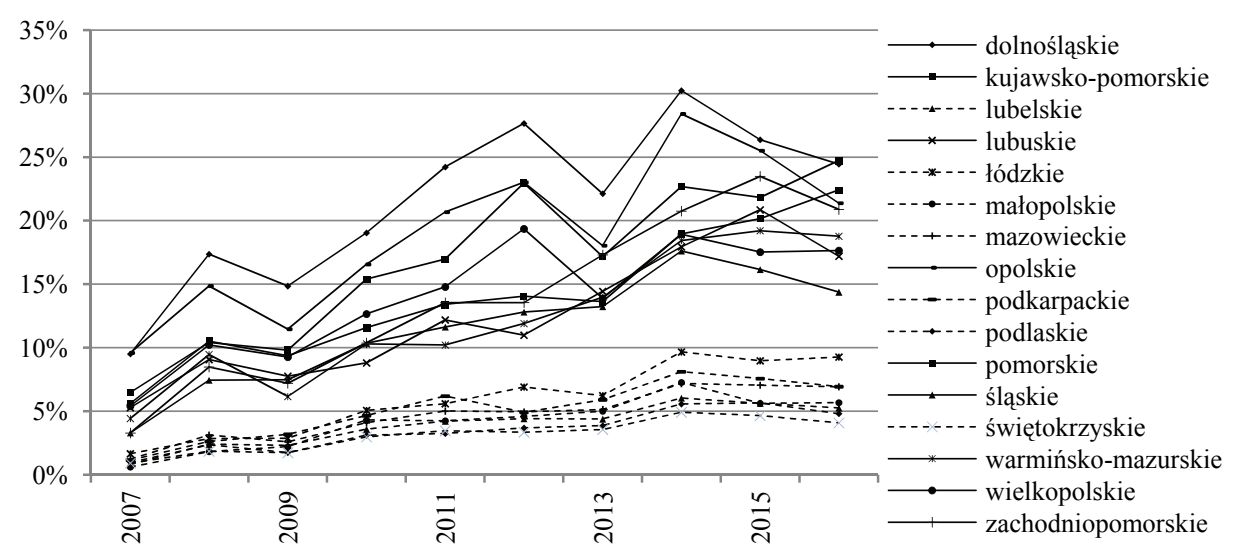

Rysunek 6. Udział powierzchni zasiewów objętej wsparciem do powierzchni obsianej lub obsadzonej kwalifikowanym materiałem siewnym według województw w latach 2007-2016

Źródło: opracowanie własne na podstawie sprawozdań ARR i danych GUS.

Ze względu na to, że w województwach z obserwowanym niskim poziomie korzystania $\mathrm{z}$ analizowanego działania obserwuje się również mniejszą niż przeciętnie $\mathrm{w}$ kraju powierzchnię gospodarstw rolnych, a w takich gospodarstwach zarówno poziom towa-

${ }^{19}$ L. Wicki, Zróżnicowanie..., op. cit. 
rowości, zakres powiązań z rynkiem ${ }^{20}$, jak i dążenie do zmniejszania ryzyka produkcyjnego jest ${ }^{21}$ są niskie, można powiedzieć, że nie działają tam bodźce prowadzące do wzrostu zapotrzebowania na nasiona kwalifikowane. Z jednej strony, wprowadzanie postępu biologicznego $\mathrm{w}$ zakresie produkcji roślinnej wynika przecież z czynników zewnętrznych, takich jak wymagania odbiorców, z drugiej zaś konieczne jest poniesienie dodatkowych kosztów związanych z zakupem kwalifikowanego materiału siewnego. $\mathrm{W}$ małych obszarowo gospodarstwach wydatki takie mogą konkurować $\mathrm{z}$ wydatkami na utrzymanie rodziny itp. Nie obserwuje się także powstawania grup producentów, których celem byłoby zaopatrzenie rolników środki do produkcji, $\mathrm{w}$ tym w kwalifikowany materiał siewny zbóż, czy ziemniaków na wzór grup producentów w innych gałęziach rolnictwa, np. w produkcji warzyw i owoców ${ }^{22}$.

Uzyskane wyniki nie potwierdzają twierdzenia o neutralności wprowadzania postępu biologicznego względem skali działalności ze względu na prawie doskonałą podzielność nośników postępu. W warunkach polskiego rolnictwa można mówić tylko o potencjalnej neutralności.

Wydaje się, że, tak jak już zauważyli niektórzy badacze, w regionach o rozdrobnionym rolnictwie występuje duża ostrożność wobec wprowadzania postępu w gospodarstwach rolnych ${ }^{23}$, a rozwój może dotyczyć tylko małej ich części i2 ${ }^{24}$ Również wykorzystanie środków na modernizację rolnictwa $\mathrm{w}$ ramach WPR było znacznie niższe $\mathrm{w}$ województwach $\mathrm{z}$ dominacja gospodarstw małych ${ }^{25}$. Wsparcie transferu postępu do gospodarstw jest skuteczne tylko w stosunku do gospodarstw, w których poszukuje się szansy rozwoju wzrostu, i które jednocześnie są w stanie współfinansować inwestycje.

\section{Podsumowanie}

Upowszechnianie postępu biologicznego $\mathrm{w}$ produkcji roślinnej $\mathrm{w}$ rolnictwie jest realizowane poprzez zakup i stosowanie kwalifikowanego materiału siewnego. Po integracji Polski z Unią Europejską zakończono wsparcie kierowane na obniżenie cen nasion kwalifikowanych i zwiększenie ich dostępności dla rolników. Doprowadziło to do zmniejszenia zużycia nasion kwalifikowanych o ponad 30\%. W 2004 roku ich udział w materiale siewnym zmniejszył się do zaledwie 10\%, podczas, gdy w krajach Europy Zachodniej było to około $50 \%$. Stało się to impulsem do uruchomienia wsparcia stosowania nasion i sadzeniaków kwalifikowanych w ramach pomocy de minimis.

W kolejnych latach od rozpoczęcia działania kwoty dotacji wzrastały. W 2014 roku było to około $120 \mathrm{mln}$ złotych, a w 2016 roku nastapił spadek do $88 \mathrm{mln}$ zł. Wsparcie obejmowało około 700 tys. ha w latach 2008-2013, a w okresie 2014-2016 było to nawet

\footnotetext{
${ }^{20}$ B. Gołębiewska, „Organizacyjno-ekonomiczne skutki zróżnicowania powiązań gospodarstw rolniczych z otoczeniem", Wydawnictwo SGGW, Warszawa 2010.

${ }^{21}$ A. Wicka, „Uwarunkowania ograniczania ryzyka w produkcji roślinnej z wykorzystaniem ubezpieczeń”, Wydawnictwo SGGW, Warszawa 2013.

22 A. Mickiewicz, B. Mickiewicz, Specyfika funkcjonowania grup producentów owoców i warzyw w Polsce. „Roczniki Naukowe SERiA”, 2015, t. XVII, z 6, 185-190.

${ }_{23}^{2}$ B. Gołębiewska, „Organizacyjno-ekonomiczne...”, op. cit.

24 W. Musiał, E. Otoliński, Rozważania nad potrzebą przemian gospodarstw rolniczych w regionach rozdrobnionych agrarnie, ,Roczniki Nauk Rolniczych. Seria G”, 2009, t. 96, z. 4, 147-154.

${ }^{25}$ R. Pietrzykowski i L. Wicki, Regionalne zróżnicowanie wykorzystania środków z programów Wspólnej Polityki Rolnej na modernizację rolnictwa, „Roczniki Nauk Rolniczych. Seria G”, 2011, t. 97, z. 4, 7-22.
} 
ponad $1 \mathrm{mln}$ ha. Udział powierzchni zasiewów objętej programem wynosił po 2013 roku około 14\% dla zbóż i 10\% dla ziemniaków. W ten sposób, w latach 2014-2016 pomoc była udzielana pośrednio do całej sprzedaży kwalifikowanych nasion i sadzeniaków w Polsce. Jej wysokość można oszacować na około $30 \%$ ceny zakupu.

Wnioski o udzielenie wsparcia składało rocznie około 70-80 tys. gospodarstw rolnych. Oznacza to, że zaledwie 5-5,5\% gospodarstw korzystało z takiego wsparcia, co wskazuje na niskie zainteresowanie stosowaniem nasion kwalifikowanych. Było ono też silnie zróżnicowane regionalnie. W województwach: kujawsko-pomorskim, wielkopolskim, opolskim i dolnośląskim udział gospodarstw korzystających ze wsparcia wynosił ponad $10 \%$, a powierzchnia zasiewów objęta wsparciem sięgała $20 \%$. Z kolei w województwach o rozdrobnionym rolnictwie (małopolskie, podkarpackie i świętokrzyskie) udział gospodarstw, które korzystały z tego działania wynosił tylko $1 \%$, zaś udział powierzchni zasiewów objętej wsparciem był mniejszy niż 5\%. Zainteresowanie wprowadzaniem postępu biologicznego do produkcji było bardzo małe w regionach o rozdrobnionym rolnictwie. Oznacza to, że upowszechnianie postępu napotyka w takich regionach na silne bariery, które mogą wynikać zarówno ze słabych powiązań gospodarstw małych $\mathrm{z}$ otoczeniem, jak też $\mathrm{z}$ ograniczonych zasobów środków finansowych, które mogłyby być przeznaczane na zakup nasion.

Wsparcie upowszechniania stosowania kwalifikowanego materiału siewnego w ramach działania prowadzonego przez Agencję Rynku Rolnego okazało się zasadne. W latach 2013-2016 obejmowało w zasadzie cała powierzchnię zasiewów, na której zastosowano kwalifikowany materiał siewny. W okresie 2008-2016 doprowadziło do zwiększenia zużycia nasion kwalifikowanych o około 30\%. Działanie to było skuteczne w stosunku do gospodarstw dużych obszarowo. W warunkach rozdrobnionego rolnictwa oferowane wsparcie nie cieszyło się istotnym zainteresowaniem i nie przyczyniło się do zwiększenia zużycia nasion kwalifikowanych.

Obserwowane oddziaływanie programu na poziom zużycia nasion kwalifikowanych może być podstawą do stwierdzenia, że w polskim rolnictwie postrzeganie ważności wprowadzania postępu biologicznego w produkcji roślinnej jest wciąż niskie i ciągle ważne jest wspieranie jego upowszechniania. Należy przypuszczać, że w perspektywie kilkunastu lat, wraz z umacnianiem się grupy rozwojowych gospodarstw rolnych, popyt na nasiona kwalifikowane nie będzie musiał być indukowany poprzez stosowanie dopłat.

\section{Literatura}

ARR (2008-2017). Sprawozdanie z działalności Agencji Rynku Rolnego 2007-2016. Agencja Rynku Rolnego, Warszawa, Polska.

Duvick D. (2005). The Contribution of Breeding to Yield Advances in Maize (Zea mays L.). Advances in Agronomy, 86, 83-145.

Fuglie K., Rada N. (2017). International Agricultural Productivity. USDA, Economic Research Service, USA. dostępne na: https://www.ers.usda.gov/data-products/international-agricultural-productivity/ (dostęp: 21.10.2017)

Gepts P. (2003). Genetic Diversity, Plant Breeding, and Sustainability. University of California: Davis, USA. Gołębiewska B. (2010). Organizacyjno-ekonomiczne skutki zróżnicowania powiqzań gospodarstw rolniczych z otoczeniem. Wydawnictwo SGGW: Warszawa, Polska.

Gołębiewska B. (2010). Inwestycje i źródła ich finansowania w gospodarstwach o zróżnicowanych powiązaniach z otoczeniem. Roczniki Naukowe SERiA, XII(3), 88-92.

Kusz D., Gędek S. (2015). Egzogeniczne i endogeniczne uwarunkowania inwestycji w rolnictwie w Polsce. Roczniki Naukowe SERiA, XVII(3), 237-242. 
Majchrzycki D. (2015). Rynek kwalifikowanego materiału siewnego pszenicy ozimej w Polsce. Roczniki Naukowe SERiA, XVII(3), 254-259.

Marciniak K. (2008). Stan polskiej hodowli roślin w roku 2008. Roczniki Nauk Rolniczych - seria G, 95(1): 166-173.

Mickiewicz A., Mickiewicz B. (2015). Charakterystyczne cechy nowego Programu Rozwoju Obszarów Wiejskich na lata 2014-2020. Roczniki Naukowe SERiA, XVII(1), 153-158.

Mickiewicz A., Mickiewicz B. (2015). Specyfika funkcjonowania grup producentów owoców i warzyw w Polsce. Roczniki Naukowe SERiA, XVII(6), 185-190.

Musiał W., Otoliński E. (2011). Rozważania nad potrzebą przemian gospodarstw rolniczych w regionach rozdrobnionych agrarnie. Roczniki Nauk Rolniczych - seria G, 96(4), 147-154.

Pietrzykowski R., Wicki L. (2011). Regionalne zróżnicowanie wykorzystania środków z programów Wspólnej Polityki Rolnej na modernizację rolnictwa. Roczniki Nauk Rolniczych - seria G, 97(4), 7-22.

Rozporządzenie Rady Ministrów z dnia 13 marca 2007 roku w sprawie wykazu gatunków roślin uprawnych, do których materiału siewnego kategorii elitarny lub kwalifikowany przysługuje dopłata z tytułu zużytego do siewu lub sadzenia materiału siewnego kategorii elitarny lub kwalifikowany (Dz. U. Nr 46, poz. 300).

Thirtle C. (1995). Technological Change and the Productivity Slowdown in Field Crops: United States, 193978. Southern Journal of Agricultural Economics, 17 (Dec.), 33-42.

Wicka A. (red.). (2013). Uwarunkowania ograniczania ryzyka w produkcji roślinnej z wykorzystaniem ubezpieczeń. Wydawnictwo SGGW: Warszawa, Polska.

Wicki L. (2006). Poziom i efekty stosowania materiału kwalifikowanego w gospodarstwach rolniczych. Roczniki Naukowe SERiA, VIII(1), 222-226.

Wicki L. (2009). Zmiany w zużyciu nasion kwalifikowanych w Polsce. Roczniki Nauk Rolniczych - seria G 96(4), 226-237.

Wicki L. (2010). Zróżnicowanie przestrzenne wykorzystania postępu biologicznego w produkcji roślinnej w Polsce. Roczniki Nauk Rolniczych - seria G, 97(4), 221-229.

Wicki L. (2010). Efekty upowszechniania postępu biologicznego w produkcji roślinnej. Wydawnictwo SGGW: Warszawa, Polska.

Wicki L. (2017). Postęp w plonowaniu odmian pszenicy ozimej i żyta w doświadczeniach odmianowych w Polsce. Roczniki Naukowe SERiA, XIX(4), 224-230.

http://dx.doi.org/ 10.5604/01.3001.0010.5191

Witzke H., Jechlitschka K., Kirschke D., Campen H., Noleppa S. (2004). Social rate of return to plant breeding research in Germany. Agrarwirtschaft, 53(5), 206-210.

\section{Summary}

It is generally accepted that the increase in plant productivity is mainly achieved through the varietal progress. For this reason, the use of certified seed is very important, and the program is expected to lead to a higher level of use of certified seeds in Polish agriculture. The aim of the study is to evaluate the level and scope of support for the dissemination of certified seed use in Poland within the measure of Agricultural Market Agency and to define its spatial differentiation. The analysis covered years 2007-2016, i.e. whole period of this measure realization.

It was found that support was indirectly provided for the whole sale of certified seed in Poland and covered around 1 million ha per year. It covered $14 \%$ of cereal production area and $1 \%$ of potato production area. The use of the program was strongly differentiated regionally. In regions with a high level of agriculture, more than $10 \%$ of farmers applied for support under the program and over $20 \%$ of the production area were supported. In regions with fragmented agriculture, it was only $1 \%$ of farmers and about $4 \%$ of sown area. Interest of the biological progress implementation in the conditions of fragmented agriculture was low and the support offered has not been effective for small farms. 
Key words: biological progress, certified seeds, de minimis aid, progress dissemination, support of agriculture

Informacja o autorze:

dr hab. Ludwik Wicki, prof. nadzw.

Katedra Ekonomiki i Organizacji Przedsiębiorstw

Wydział Nauk Ekonomicznych, Szkoła Główna Gospodarstwa Wiejskiego w Warszawie

ul. Nowoursynowska 166

02-787 Warszawa

orcid.org/0000-0002-7602-8902

e-mail: ludwik_wicki@sggw.pl 